\title{
STAKEHOLDER MANAGEMENT IN THE ALLEVIATION OF LEGAL AND REGULATORY DISPUTES IN PUBLIC-PRIVATE PARTNERSHIP PROJECTS IN SOUTH AFRICA
}

\begin{abstract}
Purpose: This study introduces the use of critical success factors (CSFs) of stakeholder management as a possible solution to reduce disputes experienced as a result of legal and regulatory issues in public-private partnership (PPP) projects.
\end{abstract}

Methodology: The epistemological positioning of this paper adopted positivism and deductive reasoning to investigate the dispute phenomena on PPP projects. A survey strategy was adopted using a structured questionnaire and closed ended Likert scales to collate primary data. Questionnaires were distributed to South African construction professionals using both purposive and snowballing non-probability sampling techniques. Data was analysed using summary statistical analysis of the CSFs identified from literature.

Findings: The study revealed that among the 19 critical success factors (CSFs) identified, five factors were highlighted that could contribute to the alleviation of disputes between stakeholders in PPP projects viz: 1) adequate project planning and control; 2) effective leadership; 3) appropriate strategies for the management of stakeholders; 4) confirmation of clear goals and objectives of the project; and 5) effective communication.

Originality: The strength of the study lies in the evaluation and use of CSFs of stakeholder management as a possible solution to minimise or even avoid disputes as a result of legal and regulatory issues in PPP projects. By integrating the CSFs, the legal and contractual misconceptions of the PPP initiative are clarified. Such work represents a novel contribution to procurement practice in South Africa and may be other countries internationally who are grappling with similar issues.

\section{KEYWORDS}

Public-private partnership projects, stakeholder management, critical success factors, legal and regulatory issues, construction project team

\section{INTRODUCTION}

The need to deliver sustainable infrastructure assets for the socio-economic well-being of the public in developing countries is increasing (Debrah et al., 2020; Owusu-Manu et al., 2020a). Alm (2011) contends that poor provision and financing of transport, water and sanitation, power supplies and communication facilities economically deprive 
developing countries from competing on a global scale. As a viable solution to a notable dearth of affordable finance to augment existing, and build new infrastructure assets (cf. Owusu-Manu et al., 2018; Donkor-Hyiaman et al., 2019; Owusu-Manu et al., 2020b, 2020c), state agencies have resorted to collaborating with private firms (Mouraviev and Kakabadse, 2015; Wang, 2015). Klijn (2010) and Ullah et al. (2016) affirm that publicprivate partnerships (PPPs) are long-term collaborations between government agencies and private firms. Albalate and Bel (2009) and Kenton (2019) add that private sector firms in PPPs are considered for financing, building and operating infrastructure assets at their own expense in return for a fee from the operations of the built asset.

Pongsiri (2002) outlines that the legal and regulatory frameworks are paramount in the determination of: clear guidelines for financial performance; responsibilities of the implementation staff; provision of adequate means to protect the interests of the private firms; and ultimately for the success delivery of infrastructure assets through PPPs. However, there are legal and regulatory issues encountered that delay projects' predetermined goals and objectives. According to Lundqvist (1988), these include regulations and contractual safeguards that have the ability to affect the competitive relevance of the private sector in the construction an civil engineering market, which leads to detrimental consequences for private firms (Savas, 2002). The challenges identified within the existing legal and regulatory frameworks are that they are unlimited in scope and also guilty of promoting micro-management and unclear operations (Pongsiri, 2002); whereas the ideal expectation of the frameworks is that they remain limited, fair, transparent and consistent.

Despite the amount of research on stakeholder management (Cleland, 1999; Newcombe, 2003; El-Gohary et al., 2006; Olander and Landin, 2008; Chinyio and Akintoye, 2008, Chinyio and Olomolaiye, 2010; Nwachukwu et al., 2017), little theoretical and empirical attention has been paid to the use of critical success factors (CSFs) of stakeholder management as a possible solution to alleviate legal and regulatory disputes experienced in the practice and implementation of PPP projects. Therefore, to address the articulated challenges experienced in PPPs, this current study provides analysis of the likelihood of adopting CSFs for stakeholder management as a feasible solution towards the alleviation of legal and regulatory disputes between 
stakeholders in the delivery of projects through PPPs. In realising this aim, associated objectives are to: engender further incisive debate within academia and practice on the palpable benefits of CRFs in the dispute prevention; and ultimately contribute to the efficient and effective delivery of infrastructure projects in South Africa and other nations with similar issues prohibiting socio-economic development.

\section{CRITICAL SUCCESS FACTORS AND REGULATIONS}

Numerous studies (Cleland, 1999; Newcombe, 2003; El-Gohary et al., 2006; Olander and Landin, 2008; Chinyio and Akintoye, 2008; Chinyio and Olomolaiye, 2010) have been conducted on CSFs of stakeholder management in construction and civil engineering projects. However, studies that explore the CSFs of stakeholder management as a possible solution to alleviate causes of disputes in PPPs are limited within the prevailing body of knowledge. Scant insight extends to a study by Mok et al. (2017) which fell short in expounding on issues relating to legal and contractual obligations of the involved stakeholders by selectively focusing and generalising stakeholder-related issues and their interrelationships only during the design-andconstruction stage. To fully understand the dispute prevention or mitigation process, a clear understanding of: the role of the public sector in the PPP; legal and regulatory issues; and a clearer understanding of CSFs must first be acquired.

\section{Understanding the role of the public sector in public-private partnerships (PPPs)}

PPPs are collaborations between public and private firms preferred for the successful delivery of public assets. Babatunde et al. (2016) and Jayasuriya et al. (2019) agree that PPPs include organizations from both the public and private sector collectively working together to share responsibilities by prioritizing the strengths of each partner for the benefit of improving the delivery of public assets. Additionally, Hoppe et al. (2013) and Kavishe et al. (2019) connotes that in terms of cost and affordability, PPPs are economically preferred compared to traditional procurement because they ensure that value for money is attained prior to the completion of the built facilities and lastly ensure the provision of affordable housing outcomes. Akintoye and Liyanage (2011) define PPPs as a strategy employed to accelerate the delivery of infrastructure assets, economic growth and development, which will in return produce quality service delivery and good governance (Ismail and Haris, 2014). 
Private firms in PPPs are often considered because they bring about value for money through the provision of private management skills used for planning, construction and delivery of public infrastructure assets (Li et al., 2005; Cheung et al., 2009). For a successful partnership there is also a requirement of fulfilling CSFs, such as the political will from the public sector to make decisions (Jayasuriya et al., 2019) that will stimulate private participation. Consequently, whether it is locally, regionally, provincially or nationally, there needs to be government buy-in. Thus, the role of government (especially as a facilitator and administrator) in PPP projects cannot be regarded as inconsequential. More importantly the success of PPPs is also dependent on the adherence of the following sustainability factors influencing PPPs viz: sustainability assessments conducted from the feasibility stage; and sustainability factors considered during the evaluation of project viability (Kavishe et al., 2019).

\section{Legal and regulatory issues in public-private partnership construction projects}

Several studies (Loosemore, 2006; Bourne and Walker, 2006; Rowlinson and Cheung, 2008) have articulated challenges affecting stakeholder management as the reason behind the failure of construction projects. These challenges include but are not limited to: lack of engagement amongst stakeholders; ineffective use of existing communication channels; and unclear and incoherent objectives provisioned by stakeholders (Jayasuriya et al., 2019). Mok et al. (2017) revealed that amongst issues pertaining to stakeholder consultation, client related issues were more evident vis-à-vis those from other stakeholders. However, this present study focuses more on legal and regulatory issues leading to disputes in PPP projects, and how the use of CSFs of stakeholder management can be used to alleviate the identifiable disputes.

The practice and implementation of PPPs involve a complex use of contracts and other necessary processes that ensure its success (Pongsiri, 2002). To guarantee the effective use of the contracts and processes, legal frameworks that facilitate infrastructure projects development are required (Institute for Public-Private Partnerships, 2000). Additionally, the importance of having an administrative framework that expedites the implementation of PPP projects cannot be over-emphasized. In 2015, to guide the practice and implementation of any PPP project, Uganda established and implemented a Public-Private Partnership Act (Mwesigwa et al., 2019). However, despite the 
establishment and implementation of frameworks there are still legal issues that arise from the practice and implementation of PPP projects. Grimsey and Lewis (2004) and Mouraviev et al. (2012) indicate that these include: enforcement of contracts; private sector interests; security arrangements; taxes; remittance of foreign exchange and profits; and bureaucracy in attaining permits and consents. Mwesigwa et al. (2019) maintain that the legal issues of PPP projects emerge from the now adopted legal and regulatory framework (established by government) that guides the facilitation of infrastructure projects delivered through PPPs and contribute to the ongoing disputes encountered in the projects.

\section{Understanding critical success factors of stakeholder management for PPPs}

Yang et al. (2009), Bakar et al. (2009), Nauman and Piracha (2016) and Mok et al., (2015) highlighted the following CSFs of stakeholder management as imperative to the successful delivery of construction projects in developed countries viz:

- $\quad$ Formulating a clear statement of project missions;

- Identifying stakeholders properly;

- Understanding the area of stakeholders' interests;

- Exploring stakeholders' needs and constraints to projects;

- Accurately predicting the influence of stakeholders;

- Analyzing conflicts and coalitions among stakeholders;

- Keeping and promoting good relationships;

- $\quad$ Formulating appropriate strategies to manage stakeholders;

- Predicting stakeholders' reactions towards the implementation of strategies;

- Analyzing the change of stakeholders' influence and relationships during the project process; and

- Communicating with and engaging stakeholders appropriately and frequently.

\section{Understanding and prioritizing stakeholders' interests, their needs and constraints}

In complex infrastructure projects such as PPP projects (which involve multiple corporations from different sectors), it is difficult to ensure that the interests, needs and constraints of each party are considered. However, with effective communication channels in place, it is possible to identify each stakeholder's interests such as integrity 
towards financial reporting, financial returns and product safety (Freeman et al., 2007). Prioritizing the interests of stakeholders includes exploring stakeholders' needs and constraints. This assists with assessing the challenges and finding possible solutions to the challenges encountered (Love et al., 2004; Wood and Logsdon, 2000). Moreover, when the issues have been identified, whether these are issues facing individuals or issues experienced as a group, it is possible to then carry out analyses and provide solutions to stakeholders' requirements (Yang et al., 2009). This can only be carried achieved through effective communication.

\section{Prioritizing and promoting trust between stakeholders}

Key delivery of construction projects and meeting stakeholders' expectations are the result of successful and stable relationships between stakeholders (Hartmann 2002), and this requires trust. Even though trust may appear as a soft skill, its importance and relevance to the success of a progressive and reliable stakeholder management team is significant. Karlsen et al. (2008) and Gudiene et al. (2013) clearly stated that in order to pursue good relations and understanding in a team, trust needs to take precedence. Rousseau et al. (1998) discussed the prominence of pursuing good relations in a partnership. Their study (ibid) revealed that trust enables cooperative behaviour and mitigates the causes of conflicts that may lead to arbitration. In fact, trust endorses effective responses to misunderstandings that may emerge during partnership proceedings. Mohr and Spekman (1994) concur that trust realized between stakeholders can indeed improve adaptability, encourage a united problem-solving space and guarantee better outcomes of the PPP project. The findings of Mwesigwa et al. (2019) stressed trust as an insignificant attribute of stakeholder management but a necessary component nonetheless, further highlighting that trust is built up over a long period; thus, it will be unwise to prioritize it.

\section{Affirming commitment among stakeholders}

Commitment in stakeholder management is defined as the stakeholders' ability in a partnership to serve the project aims with absolute loyalty (Mwesigwa et al., 2019), while Meyer and Allen (1997) indicated that stakeholders' sense of responsibility to remain in the project, stakeholders' emotional attachment and stakeholders' recognition of the benefits of the project in the long run are the three forms of commitment that 
preserve stakeholders' committment to a project. According to Tellefsen and Thomas (2005), commitment is one of the qualities required to fulfil a long-term relationship in PPPs, ensuring that goals and objectives of the project are met. Commitment cannot be stressed enough as an important attribute in stakeholder management. Mwesigwa et al. (2019) however, states that commitment along with trust is an insignificant attribute to stakeholder management for PPP projects in Uganda. Nevertheless, it is a necessary attribute to have. The literature reveals that trust and commitment are attributes that can be realized between stakeholders working together in the PPP projects over the contract period.

\section{RESEARCH METHODOLOGY}

The adopted epistemology was couched in a positivist philosophical stance (cf. Pärn et al., 2018; Edwards et al., 2020a; Hou et al., 2020) and deductive reasoning (cf. Ghansah et al., 2020) to investigate the dispute phenomena on PPP projects. From a methods perspective, a survey strategy was adopted (cf. Owusu-Manu et al., 2018; Edwards et al., 2020b) using approach whereby a structured questionnaire and closed ended Likert scales to collate primary data (cf. Aghimien et al., 2020). Questionnaires were used because they represent an economical means of collect field data and using such to generalize results in order to provide coherent recommendations (Muredzi, 2019). The questionnaire had two sections: Section A collected demographic information from respondents to ensure that they could effectively contribute to this study (by meeting minimum entry criteria). Section B dealt with the likelihood of using CSFs of stakeholder management to alleviate disputes experienced as a result of legal and regulatory issues between stakeholders in the practice and implementation of PPP projects. To rate the likelihood, a five-point Likert scale was adopted, with 5 being 'very likely, 4 being 'likely', 3 being 'undecided', 2 being 'unlikely' and 1 being 'very unlikely'.

\section{Sampling and distribution frame}

Questionnaires were was distributed to trained and experienced South African construction professionals using both purposive and snowballing non-probability sampling techniques (cf. Owusu-Manu et al., 2020d). Knowledge and experience of managing construction and/or civil engineering project was set as the minimum entry 
criteria to ensure that only valid and insightful comments were collated. Consequently, to achieve this objective, construction professionals affiliated to prominent institutions were targeted - key professions were quantity surveyors, construction project managers, project managers, engineers, programme implementation managers, town planners, site managers and health, safety and environment (HSE) officers. Initially, 12 public and private institutions located in the Gauteng Province, South Africa were nominated. The number further increased owing to a snowball sampling technique. The research findings of the study may not be generalised for the entire Gauteng Province, South Africa as this study only featured a few areas within the province.

Sedgwick (2013) asserts that a snowball sampling technique initially identifies potential respondents of the study who will eventually recruit other participants. The respondents that were identified in the initial 12 institutions further recruited other participants, both from within their institutions and from outside. As a non-probability technique, snowball sampling encourages the participation of respondents who are not comfortable with directly dealing with the researcher (it provides a sense of anonymity) (Bhat, 2019) or sampling respondents who are out of reach. The initial sample size of an unknown population was obtained using equation 1, and this amounted to 96 respondents.

$$
\begin{aligned}
& n=\frac{p(1-p) \mathrm{z}^{2}}{E_{2}} \begin{array}{c}
n=\text { sample size } \\
\mathrm{P}=\text { percentage occurrence of a state/condition (estimation of the variance/heterogeneity }
\end{array} \\
& \text { of the population); } \mathrm{E}=\text { percentage of maximum error/ margin of error (level of } \\
& \text { precision); and } \mathrm{Z}=\text { value corresponding to the level of confidence }
\end{aligned}
$$

To calculate the sample size of an unknown population 95\% (1.96) of the level of confidence $(Z)$ was selected. Given the attributes of the adopted sampling techniques, this was the percentage to which the characteristics of the population can be generally estimated by the sample survey. This simply suggests that 95 out 100 samples obtained will be a definite reflection of the population (Taherdoost, 2017). In case of miscalculations or change of circumstances $\pm 10 \%$ was allocated for the margin of error. Olatunji et al. (2016) in a study that assessed factors affecting the performance of 
undergraduate students (as well as in construction and other related disciplines) used $\pm 10 \%$ as the margin of error as an acceptable figure. Bartlett et al. (2001) point out that since the calculation of the percentage of occurrence $(\mathrm{P})$ can be calculated prior to the survey it is acceptable to take $50 \%$ as an estimate. This will maximize the variance and produce a maximum sample size. Thus, the sample size computed from equation 1 amounted to 96 , however given the application of the snowballing technique the size slightly increased. The increase or limited distribution of questionnaires in snowballing is attributed to the willingness of the identified respondents to recruit other participants.

\section{Pilot and main survey}

A pilot study was undertaken before questionnaires were distributed to confirm face validity. The questionnaire was sent to three random doctoral candidates and three construction professionals to verify and validate the research instrument's clarity and completeness - all pilot study participants had experience in questionnaire design and development. Following minor suggestions for improvement, a revised questionnaire was then approved and deemed ready for distribution. Subsequent to data collection Cronbach's alpha test was carried out to determine the reliability of the research instrument. The alpha value generated was 0.963. According to Moser and Kalton (1999) and Pallant (2001), a Cronbach's alpha value that is over 0.60 renders the research instrument in question reliable.

As a result of the snowball sampling technique it was difficult to determine the exact number of questionnaires distributed in total. However, from an unknown number of questionnaires distributed, 62 participants responded to the invitations sent via Google Forms, while 23 physical copies of the 36 distributed via surface mail were returned. Given the study's objective to ascertain the likelihood of using CSF of stakeholder management and observed varying degrees of understanding the subject under investigation, as well as the resources at the disposal of the researcher the number of the returned questionnaires was deemed adequate. Not more than $60 \%$ of the participants have not participated in PPP projects, indicating that more professionals in the construction industry have not taken part in PPP projects whilst those that have participated in at least five PPP projects did not surpass 10\% mark. Taherdoost (2016) postulates that whilst the proportion of the population is not entirely the focal point 
during sampling the complexities of the population in the selected sample must not be neglected.

Subsequent screening of the 85 questionnaires returned revealed that only 62 were eligible for further analysis. Data analysis was conducted using Statistical Packages of Social Sciences (SPSS) version 26.. Frequencies and percentages were used to analyse the respondents' background information. To determine the normality of the received data Shapiro-Wilk test was conducted and to assess the likelihood of whether the identified CSFs are key measures for alleviating legal and regulatory disputes, the use of mean item scores (MISs), standard deviation (SD) and ranks (Rs) were adopted.

\section{FINDINGS}

The analysis of demographic profile reveals that quantity surveyors dominated the study with $62.9 \%$ (frequency $(f)=39$ ) while construction projects managers amounted to only $17.7 \%(\mathrm{f}=11)$. From the number of respondents who took part in the study $41.9 \%(f=$ 26) of them were registered with various councils, $17.7 \%(f=11)$ of the respondents were registered with the South African Council of Quantity Surveying Profession (SACQSP) while 14.5\% $(f=9)$ were registered with the South African Council Construction Project Management Profession (SACPCMP). The respondents were then asked to indicate which organization they belonged to. A total of $38.7 \%(f=24)$ indicated that they operate under contractors, while $32.3 \%(f=20)$ indicated that they operate under consultants. When asked to indicate whether they have participated in any PPP projects $40.3 \%(f=25)$ indicated that they had. From the batch that responded positively, $32.2 \%(f=20)$ of them had undertaken one or two PPP projects. According to the results, $29 \%(f=18)$ of those projects were undertaken in the Gauteng Province.

\section{Critical success factors on stakeholder management}

The study further determined the likelihood of using the CSFs of stakeholder management to alleviate disputes experienced as a result of legal and regulatory issues between stakeholders in the practice and implementation of PPPs. MIS was used in this regard, but beforehand data normality was determined using the Shapiro-Wilk Test which is suitable for any sample size $>2,000$ (Ghasemi and Zahediask, 2012). This was to determine whether parametric or non-parametric tests would be suitable for this 
particular study. From Table 1 below it is clear that the significance value of all 19 CSFs identified in the literature reviewed is less than the required $p=0.05$ which renders this data non-parametric.

\section{$<$ Insert Table 1 about here $>$}

From Table 1 it is clear that the respondents agree that all the mentioned CSFs of stakeholder management are essential for alleviating disputes between stakeholders as a result of legal and regulatory issues. However, according to the ranking conducted: 'ensuring adequate project planning and control' (MIS $=4.24$; $\mathrm{SD}=0.88$ ); 'providing effective leadership' (MIS $=4.23$; $\mathrm{SD}=0.85$ ); 'formulating appropriate strategies for the management of stakeholders' (MIS $=4.23$; $\mathrm{SD}=0.98$ ); and 'confirming clear goals and objectives of the project' (MIS $=4.21 ; \mathrm{SD}=0.97$ ) took precedence over other factors with a ranking of 1, 2, 3 and 4 respectively. 'Guaranteeing competitive and transparent procurement approaches' (MIS $=4.00 ; \mathrm{SD}=0.99$ ); 'understanding stakeholders' interest areas' (MIS $=4.00 ; \mathrm{SD}=1.00$ ); and 'promoting tested legal and regulatory frameworks' (MIS $=4.00 ; \mathrm{SD}=1.0$ ) were ranked 11,12 and 13 respectively. 'Certifying public/community support' (MIS $=3.85$; SD $=1.00$ ); ' analysing the change of stakeholders' influence and relationships' (MIS $=3.81$; $\mathrm{SD}=1.0$ ); and 'predicting stakeholders' reactions for implementing strategies' (MIS $=3.81 ; \mathrm{SD}=1.00$ ) were the last three CSFs of stakeholder management required to alleviate disputes experienced as a result of legal and regulatory issues in PPP projects according to the rankings.

\section{DISCUSSION OF FINDINGS}

From literature reviewed, it was evident that issues pertaining to legal and regulatory matters of PPPs indeed contribute to conflicts among stakeholders, and that conditions and regulations in many developing countries have not been clearly defined to alleviate disputes incurred. (Kavishe et al., 2019). Ping Ho et al. (2015) indicates that there is a need to create favourable conditions for PPPs projects to flourish in terms of improved stakeholder management - which in itself requires good governance, effective pricing strategies and clear transaction costs. The literature revealed that enforcement of contracts, bureaucracy regarding attaining permits and consent, and remittance of foreign exchange and profits (Mouraviev et al., 2012; Mwesigwa et al., 2019) are 
amongst the legal and regulatory issues leading to disputes among stakeholders. Consequently, the study envisaged to improve the way the stakeholders handle issues related to legal and regulatory matters by introducing the CSFs of stakeholder management.

Using the mean item score in Table 1, it is evident that all the 19 acknowledged CSFs of stakeholder management are likely to be used to alleviate disputes among stakeholders as a result of legal and regulatory issues. However, in determining the importance of the CSFs using the ranking, it is also evident that 'ensuring adequate project planning and control', 'providing effective leadership' and 'formulating appropriate strategies for the management of the projects team' were also essential in alleviating disputes as a result of legal and regulatory issues in the practice and implementation of PPPs. Hajdu et al. (2013) concurred with the findings and indicated that planning and controlling project activities using Gantt charts for example, improves the working relationship within the project team, thus providing clarity to any bureaucratic glitches encountered in PPP arrangements. This also involves the development of network planning techniques. Aigbavboa and Thwala (2014) further concurred with this present study's results on the fact that effective leadership should be prioritized in PPP projects, especially where personalities collide due to misunderstandings regarding the legal and contractual obligations of the PPP frameworks (Karlsen, 2002; Schwager, 2004). In massive and ambiguous projects such as the PPPs, it is more than likely that personalities will collide. El-Sawalhi and Hammad (2015) made emphasis on the importance of the project manager's competencies as a key factor affecting management support of stakeholders One recommended strategy to augment understanding and improve relations between stakeholders is the use and emergence of 'response strategies' between stakeholders (Sivonen, 2009) - that is, identifying what stakeholders will do to mitigate project risks identified.

Confirming clear project goals and objectives, and ensuring effective communication were within the top five CSFs preferred for the alleviation of disputes experienced. Aigbavboa and Thwala (2014) further encouraged the prioritization of clearly defined project objectives and the use of integrated procurement processes which concurs with the findings of this study. The results from El-Sawalhi and Hammad (2015) clearly 
revealed that setting common goals and objectives for construction projects takes precedence and influences information input more than identifying stakeholders and exploring the needs and expectations of stakeholders. The importance of defining goals and objectives in complex projects such as the PPPs is of paramount importance (England and Macdonald, 2015) to their success. This involves determining the expectations and roles of each stakeholder in the project (Winch, 2000). To ensure that each member of the project team understands the stipulated roles and objectives of the project there needs to be effective communication. Highlighted as a critical factor in the alleviation of legal and regulatory disputes (Olander and Landin, 2008; Walker et al., 2008), effective communication produces, nurtures and manages relationships and encourages comprehension of complex matters relating to the legal and regulatory frameworks of PPPs. El-Sawalhi and Hammad (2015) and Mwesigwa et al. (2019), as also observed in this present study, add that communication is the most preferred factor affecting the decision making of alleviating legal and regulatory disputes in the practice and implementation of PPP projects even more than trust, commitment or engagement.

However, Karlsen (2008) and Nauma and Piracha (2016) disagree with the findings of this present study and maintain that communication along with trust, commitment and engagement are significant in resolving and improving relationships within the project team. Tellefsen and Thomas (2005) also argue that commitment is key in sustaining long-term relationships (contracts) such as the ones experienced in PPPs. As this present study shows in Table 1, trust, commitment and engagement are likely to be used for alleviating disputes. However, in terms of ranking, they were not included in the top five of the essential CSFs that are likely to alleviate disputes as result of legal and regulatory issues between stakeholders in PPP projects. Interestingly, Abdullah et al. (2010) evidently favoured the prioritization of engagement over trust and commitment. The issue behind the dubious prioritization of trust and commitment is that both attributes are characteristics one can inherently reveal over a long period of time of working together. To try and prioritize and enforce them in the early stages of the partnerships is premature. However, Karlsen et al. (2008) and Gudiene et al. (2013) contend that in order to pursue good relations and understanding in a team, trust needs to take precedence. El-Sawalhi and Hammad (2015) further advocated for the understanding of stakeholder's interests as a CSF in influencing stakeholder assessment 
along with analysing conflicts among stakeholders - however, the results of this present study was not in agreement, revealing that though essential understanding of stakeholder's interests and analysing conflicts among stakeholders were not prioritised ranking twelve and sixteen respectively.

\section{LIMITATIONS AND FUTURE WORK}

There are several limitations of this study that should be highlighted as these provide fertile grounds for future study. First and foremost, the geographical distribution of the work is limited to a specific area of South Africa, and although literature was used to deductively analyse CSFs, a wider population of construction and civil engineering professionals across several developing countries could yield stronger scientific inference for a wider population. Second, the study is premised upon the presupposition that opinion is reality and moreover, that researchers' axiology and bias may be introduced into the data collection instrument (inherent weaknesses of questionnaire surveys). Whilst questionnaires are certainly less biased than interviews (given their remote application), future work is required to conduct a longitudinal study to measure the actual success or otherwise of factors identified in this study. Techniques such as fuzzy synthetic evaluation or structured equation modelling may be useful in this respect. Third, and linked to the previous limitation the complex interconnectivity or CSFs and the actors (stakeholders) involved in a PPP project implementation is not apparent within this two-dimensional and seminal work. So this work provides a important cornerstone upon which other follow-on work will transpire but it clearly does not provide a panacea to the problem reported upon. Finally, aspects of the digital digital transformation underway within contemporary construction and civil engineering management did not feature prominently in this work and so concepts such as Industry 4.0 (cf. Newman et al., 2020; Ghosh et al., 2020) were conspicuous by their absence

\section{CONCLUSION AND RECOMMENDATIONS}

The study's objective was to determine the likelihood of using CSFs of stakeholder management to alleviate disputes experienced as a result of legal and regulatory issues (such as poor administration or frameworks) that affect the implementation of PPP projects. The study however, fell short in expounding on the importance and determinant of stakeholder attitudes in PPP projects, which is a significant attribute to consider in stakeholder assessment. Stakeholder attitude identifies which stakeholders 
are in support of the project and whom are not, as this may have a direct positive or negative impact on the proceedings of the project. Based on the study's findings it can be concluded that, amongst other strategies, there is a possible link in the alleviation of legal and regulatory disputes with the use of CSFs of stakeholder management. The findings reveal that all 19 CSFs of stakeholder management can be used as a solution to alleviate disputes caused by misunderstanding legal and regulatory matters. However, the most significant of the 19 were 'ensuring adequate project planning and control'; 'providing effective leadership'; 'formulating appropriate strategies for the management of stakeholders'; 'confirming goals and objectives of the project'; and 'ensuring effective communication'.

Based on the study's findings it is recommended that (given a host country's conditions and regulations and, the magnitude and complexity of the PPP project) it is essential to firstly prioritize the definition and clarity of legal and contractual obligations of the PPP Acts and frameworks. For sustainability assessments this needs to be done from the project's feasibility stage. To ensure that each participant is conscious of the unstable outcomes of the projects (such as uncertainties associated with long-term contracts and the initial complex financing arrangements agreed upon), it is imperative to establish channels and feedback mechanisms that will inform the stakeholders of the ongoing status of the project. This also assures accountability, transparency, responsiveness and co-operation. Effective communication is also a recommended factor highlighted for its role of transmitting accurate, reliable and timely information between stakeholders. Whether it is a web-based means of digital communication or the integration of webbased and conventional methods, it is critical for the project manager to show leadership qualities in enforcing the innovated and improved means of transmitting information and knowledge. Additionally, since they are responsible for stakeholder management, project managers need to reveal leadership qualities in terms of ensuring adequate project planning and controlling of activities in the practice and implementation of PPP projects. In order to understand the programmes of the PPP initiative, the use and development of network planning techniques is imperative. A true understanding of the legal and regulatory frameworks of PPP in the practice and implementation of PPP projects can be achieved through the improved use of CSFs of stakeholder management as shown in this study. 
Journal of Engineering, Design and Technology

Page 16 of 28

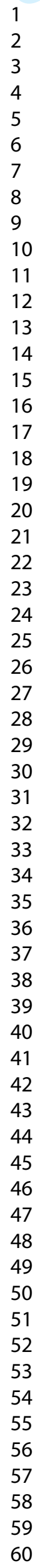$$
5
$$

16 


\section{REFERENCES}

Abdullah, A.A., Rahman, H.A., Harun, Z., Alashwal, A.M. and Beksin AM. (2010), "Literature mapping: a bird's eye view on classification of factors influencing project success". African Journal of Business Management, Vol. 4 No 19, pp. 4174-4182.

Aghimien, D.O., Aigbavboa, C., Edwards, D.J., Mahamadu, A-M., Olomolaiye, P., Onyia, M., and Nash, H. (2020) A fuzzy synthetic evaluation of the challenges of smart city development in developing countries, Smart and Sustainable Built Environment DOI: https://doi.org/10.1108/SASBE-06-2020-0092

Albalate, D. and Bel, G. (2009), "Regulating concessions of toll motor ways: an empirical study on fixed vs. variable term contracts". Transportation Research Part A: Policy and Practice, Vol. 43 no2, pp. 219-229.

Akintoye, A. and Liyanage, C. (2011), "Public-private partnerships". Proceedings of the CIBTG72/ ARCOM Doctoral Research Workshop, 12 October. Preston: University of Central Lancashire.

Australian Constructors Association. (2015), Changing the game: how Australia can achieve success in the new world of Mega-projects. [online] Available from: www.constructors.com.au/wp-content/uploads/ 2015/11/Changing-the-GameMega-Projects-Final1.pdf [Accessed 12 April 2016].

Alm, J. (2011), Municipal finance of urban infrastructure: Knowns and unknowns. Brookings: Wolfensohn Center for Development, pp. 1-13.

Babatunde, S.O., Lei Zhou, S.P. and Udeaja, C. (2016), "Stakeholder perceptions on critical success factors for public-private partnership projects in Nigeria". Built Environment Project and Asset Management, Vol. 6 no1, pp.74-91.

Bakar, A., Hassan, A., Abd Razak, A., Abdullah, S. and Awang, A. (2009), Project management success factors for sustainable housing: a framework. [online] Available from: https://www.researchgate.net/profile/Abu_Hassan_Abu_Bakar3/publication/228 518234 Project management success_factors for_sustainable housing_a fram ework/links/0046351679ae67e851000000.pdf [Accessed 29 July 2019]

Bartlett, J.E., Kotrlik, J.W. and Higgins, C.C. (2001), "Organizational Research: Determining Appropriate Sample Size in Survey Research". LP Journal, Vol. 19, pp. 43-50. 
Bhat, A. (2019), Snowball Sampling: Definition, Method, Advantages and Disadvantages. [online] Available from: https://www.questionpro.com/blog/snowball-sampling/. [Accessed 29 July 2019].

Bloomfield, P. (2006), "The challenging business of long-term public-private partnerships: reflections on local experience". Public Administration Review, Vol. 66 No3, pp. 400-411.

Brown, L. and Hicks, E. (2013), "Stakeholder engagement in the design of social accounting and reporting tools". In: L. Mook (Ed.) Accounting for Social Value. University of Toronto Press: Toronto, pp. 85-116.

Chen, C. (2009), "Can the pilot BOT project provide a template for future projects? A case study of the Chengdu No. 6 Water Plant B Project”. International Journal of Construction Project Management, Vol. 27 No.6, pp. 573-583.

Cheung E., Chan, A.P.C., Kajewski, S. (2009), "Enhancing value for money in public private partnership projects: findings from a survey conducted in Hong Kong and Australia compared to findings from previous research in the UK", Journal of Financial Management of Property and Construction, Vol. 14 No.1, pp. 720.

Chinyio, E.A. and Akintoye, A. (2008), "Practical approaches for engaging stakeholders: findings from the UK". Journal of Casting and Materials Engineering, Vol. 26 No.6, pp. 591-599.

Chinyio, E. and Olomolaiye, P.O. (2010), Construction Stakeholder Management. Chichester: John Wiley \& Sons.

Cleland, D.I. (1999), Project Management Strategic Design and Implementation. New York: McGraw-Hill.

Colton, R., Frisof, K.B. and King, E.R. (1997), "Lessons for the health-care industry from America's experience with public utilities". Journal of Public Health Policy, Vol.18, pp. 389-400.

Debrah, C., Owusu-Manu, D.G., Kissi, E., Oduro-Ofori, E. and Edwards, D. J. (2020) Barriers to green cities development in developing countries: evidence from Ghana, Smart and Sustainable Built Environment DOI: https://doi.org/10.1108/SASBE-06-2020-0089 
De Schepper, S., Dooms, M. and Haezendonck, E. (2014), "Stakeholder dynamics and responsibilities in public-private partnerships: a mixed experience". International Journal of Project Management, Vol. 32 No. 7, pp. 1210-1222.

Donkor-Hyiaman, K. A., Pärn, E. A. Owusu-Manu, D., Edwards, D. J. and Aigbavboa, C. (2019) Pension reforms, risk transfer and housing finance innovations. Journal of Housing and the Built Environment. 24(4), pp. 1149-1167. DOI: https://doi.org/10.1007/s10901-019-09698-4

Edwards, D.J., Rillie, I., Chileshe, N. Lai, J., Hossieni , M. Reza, and Thwala, W.D. (2020a) A field survey of hand-arm vibration exposure in the UK utilities sector, Engineering, Construction and Architectural Management. DOI: https://doi.org/10.1108/ECAM-09-2019-0518

Edwards, D.J., Martek, I., Hossseini, Reza, M., Ejohwomu, O. and Aigbavboa, C. (2020b) Hand-arm vibration management: an operational health and safety strategy framework. International Journal of Building Pathology and Adaptation. DOI: https://doi.org/10.1108/IJBPA-09-2020-0079

El-Gohary, N.M., Osman, H. and El-Diraby, T.E. (2006), "Stakeholder management for public private partnerships". International Journal of Project Management, Vol. 24 No.7, pp.595-604.

El-Sawalhi, N.I and Hammad, S. (2015), "Factors affecting stakeholder management in construction projects in the Gaza Strip". International Journal of Construction Management, Vol. 15 No.2, pp. 157-169.

England, H. and MacDonald, M. (2015), "Practical considerations for the design and implementation of refurbishment projects of historic school buildings", available at: https://historicengland.org.uk/ images-books/publications/practicalconsiderations-refurbishment-historic-school-buildings/ (accessed March 31, 2017).

Eschenbach, R.C. and Eschenbach, T.G. (1996), "Understanding why stakeholders matter". Journal of Metallurgical Engineering, Vol. 12 No.6, pp.59-64.

Eskerod, P. and Jepsen, A.L. (2013), Project stakeholder management (fundamentals of project management). Farnham, Surrey, England: Gower.

Eyiah-Botwe, E., Aigbavboa, C.O. and Thwala, W. D. (2016), "Critical success factors for enhanced stakeholder management in Ghana". The Scientific Journal for 
Theory and Practice of Socio-Economic Development, Vol. 5 No.10, pp. 153170.

Freeman, E. (1984), Strategic Management: a Stakeholder Approach. Boston: Pitman Inc.

Freeman, R.E., Harrison, J.S. and Wicks, A.C. (2007), Managing for Stakeholders: Survival, Reputation, and Success. London: Yale University Press.

Ghansah, F.A., Owusu-Manu, D., Ayarkwa, J., Darko, A. and Edwards, D.J. (2020) Underlying Indicators for Measuring Smartness of Buildings in the Construction Industry, Smart and Sustainable Built Environment. DOI: https://doi.org/10.1108/SASBE-05-2020-0061

Ghosh, A., Edwards, D.J. and Hosseini, M. Reza. (2020) Patterns and trends in internet of things (IoT) Research: Future applications in the construction industry, Engineering Construction and Architectural Management. DOI: https://doi.org/10.1108/ECAM-04-2020-0271

Grimsey, D. and Lewis, M.K. (2004), Public Private Partnerships: The Worldwide Revolution in Infrastructure Provision and Project Finance. Cheltenham: Edward Elgar.

Gudiené, N., Banaitis, A., Podvezko, V. and, Banaitienè, N. (2014),“Identification and evaluation of the critical success factors for construction projects in Lithuania: AHP approach". Journal of Construction Engineering and Management, Vol. 20 no.3, pp. 350-359.

Hajdu, M., Szenik, G. and Bardócz, G. (2013), “Application of Evaluation Lines in Project Planning and Control”. Social and Behavioral Sciences, Vol. 74, pp. 175-180.

Harris, F.C. (2010), “A historical overview of stakeholder management". In: E. Chinyio and P. Olomolaiye (Eds) Construction Stakeholder Mangement, Chichester: Wiley-Blackwell.

Hartmann, F.T. (2002), “The role of trust in project management”. In: D. P. Slevin, D. I. Cleland and J. K. Pinto (Eds.) Frontiers of Project Management Research. Newtown Square, Pennsylvania, pp. 225-235.

Hassan, M.M. (1996), "Let's end the non-profit charade". New England Journal of Medicine, Vol. 334, pp. 1055-7. 
HM Treasury. (2014), Improving infrastructure delivery: project initiation route. [online] Available from: www.gov.uk/government/organisations/infrastructureuk [Accessed 6 April 2016].

Hoppe, EA,. Kusterer, D.J and Schmitz, P.W. (2013), "Public-private partnerships versus traditional procurement: an experimental investigation”. J Econ Behav Organ. Vol. 89, pp. 145-166

Hou, H., Lai, Joseph H.K., and Edwards, D.J. (2020) Gap theory based post-occupancy evaluation (GTbPOE) of dormitory building performance: a case study and a comparative analysis, Building and Environment. DOI: https://doi.org/10.1016/j.buildenv.2020.107312

Hou, T.Y. (2014), Critical Success Factors for Internal Stakeholder Management in Malaysian Construction Projects. Master of Science in Project Management. A dissertation submitted to the Department of Build Environment, Faculty of Engineering and Science, Universiti Tunku Abdul Rahman.

Institute for Public-Private Partnerships (IP3). (2000), Structuring and negotiating legal agreements for public-private partnership projects. Training Workshop, Washington.

Jayasuriya, S., Zhang, G. and Yang, R.J. (2019), “Challenges in public private partnerships in construction industry: A review and further research directions". Built Environment Project and Asset Management, Vol.9 No.2, pp. 172-185.

Jergeas, G.F., Williamson, E., Skulmoski, G.J. and Thomas, J.L. (2000), “Stakeholder Management on Construction Projects". AACE International Transactions, Vol. $12, \mathrm{pp} .1-5$.

Johns, T. and Gratton, L. (2013), "Spotlight on the future of knowledge work: the third wave of virtual work". Harvard Business Review, Vol. 91 No.1, pp. 66-73.

Karlsen, J.T. (2002), "Project stakeholder management". Journal of Environmental Management, Vol. 14 No.4, pp. 19-24.

Karlsen, J.K., Græe, K. and Massaoud, M.J. (2008), "Building trust in projectstakeholder relationships". Baltic Journal of Management, Vol. 3 No.1, pp. 722.

Kavishe, N., Jefferson, I and Chileshe, N. (2019) "Evaluating issues and outcomes associated with public-private partnership housing project delivery: Tanzanian 
practitioners' preliminary observations", International Journal of Construction Management, Vol. 19 No.4, pp. 354-369

Kenton, W. (2019), Terotechnology. [online] Available from: https://www.investopedia.com/terms/t/terotechnology.asp. [Accessed 29 July 2019].

Klijn, E.H. (2010), "Public-private partnerships: deciphering meaning, message and phenomenon". In: G.Hodge and C.Greve (Eds.) Handbook Public Private Partnership. Edward Elgar, pp. 68-80.

Kurniawan, F., Ogunlana, S. and Motawa, I. (2014), “Stakeholders' expectations in utilizing financial models for public-private partnership projects". Built Environment Project and Asset Management, Vol. 4 No.1, pp. 4-21.

Li, B., Akintoye, A., Edwards, P.J. and Hardcastle, C. (2005), "Perceptions of positive and negative factors influencing the attractiveness of PPP/PFI procurement for construction projects in the UK: findings from a questionnaire survey". Journal of Engineering, Construction and Architectural Management, Vol.12 No.2, pp. 125-148.

Lock, D. (2007), Project management 9th edition. Burlington, VT: Gower.

Loosemore, M. (2006), "Managing project risks". In: S.Pryke and H. Smyth (Eds.) The Management of Complex Projects: A Relationship Approach. Blackwell Publishing Ltd, Oxford, pp. 187-204.

Love, P.E.D., Irani, Z. and Edwards, D. J. (2004), "Industry-centric benchmarking of information technology benefits, costs, risks for small-to-medium sized enterprises in construction". Automation in Construction, Vol. 13 No.4, pp. 507524.

Lundqvist, L. (1988), "Privatisation: towards a concept for comparative policy analysis". Journal of Public Policy, Vol. 8 No.1, pp. 1-19

Marques, R.C. (2018), "Is Arbitration the Right Way to Settle Conflicts in PPP Arrangements?” Journal of Management in Engineering, Vol. 34 No.1, pp. 05017007-1-05017007-7.

Menoka, B., Bryde, D., Fearon, D. and Ochieng, E. (2013), "Stakeholder engagement: achieving sustainability in the construction sector". Sustainability, Vol. 6 No.2, pp. $695-710$. 
Meyer, J.P. and Allen, N.J. (1997), Commitment at the Workplace: Theory, Research and Application, Sage Publications. CA: Thousand Oaks.

Mohr, J. and Spekman, R. (1994,), Characteristics of partnership success partnership attributes, communication behavior, and conflict resolution techniques. Strategic Management Journal, Vol.15 No.2, pp. 135-152.

Mok, K.Y., Shen, G.Q. and Yang, J. (2015), "Stakeholder management studies in mega construction projects: a review and future directions". International Journal of Project Management, Vol. 33 No.2, pp. 446-457.

Mok, K.Y., Shen, G.Q and Yang, R.J. (2017), “A network theory-based analysis of stakeholder issues and their interrelationships in large construction projects: a case study". International Journal of Construction Management, Vol. 17 No.3, pp. 210-227.

Moser, C.A. and Kalton, G. (1999), Survey Methods in Social Investigation. 2nd edition. Gower Publishing Company Ltd, Aldershot.

Mouraviev, N., Kakabadse, N. and Robinson, I. (2012), "Concessionary nature of public-private partnerships in Russia and Kazakhstan: a critical review". International Journal of Public Administration, Vol. 35 No.6, pp. 410-420.

Mwesigwa, R., Bagire, V., Ntayi, J.M. and Munene, J.C. (2019), "Antecedents of stakeholder management in public private partnership projects in Uganda". World Journal of Entrepreneurship, Management and Sustainable Development.

Muredzi, P. (2019), Innovative and Quality Research Methods for the $21^{\text {st }}$ Century Workshop. PPT on Quantitative Research: Paradigms, Research Designs, Data collection Tools and Analysis. Harare Institute of Technology, Harare: Zimbabwe.

Nauman, S. and Piracha, M.S.S. (2016), "Project Stakeholder Management - A Developing Country Perspective". Journal of Quality and Technology Management, Vol. 12 No.2; pp. 1-24

Newcombe, R. (2003), "From client to project stakeholders: a stakeholder mapping approach”. Journal of Casting and Materials Engineering, Vol. 21 No.8, pp. 841-848.

Newman, C., Edwards, D.J., Martek, I., Lai, J. and Thwala, W.D. (2020) Industry 4.0 Deployment in the Construction Industry: A Bibliometric Literature Review and 
UK-based Case Study, Smart and Sustainable Built Environment DOI: https://doi.org/10.1108/SASBE-02-2020-0016

Mouraviev, N. and Kakabadse, N.K. (2015), "Legal and regulatory barriers to effective public-private partnership governance in Kazakhstan". International Journal of Public Sector Management, Vol.28 No.3, pp. 181-197.

Nwachukwu, C.V., Udeaja, C., Chileshe, N. and Okere, C.E. (2017), "The critical success factors for stakeholder management in the restoration of built heritage assets in the UK". International Journal of Building Pathology and Adaptation, Vol. 35 No.4, pp. 304-331.

Olander, S. (2007), "Stakeholder impact analysis in construction project management". Journal of Casting and Materials Engineering, Vol. 25 No.3, pp. 277-287.

Olander, S. and Landin, A. (2008), "A comparative study of factors affecting the external stakeholder management process". Journal of Casting and Materials Engineering, Vol. 26 No. 6, pp. 553-561.

Olatunji, S.O., Aghimien, D.O., Oke, A.E. and Akinkunmi, T. (2016), “Assessment of maintenance management culture of tertiary institutions in Nigeria". Civil and Environmental Research, Vol. 8 No.6, pp. 98-105.

Osei-Kyei, R. and Chan, A.P. (2015), "Review of studies on the Critical Success Factors for Public-Private Partnership (PPP) projects from 1990 to 2013”. International Journal of Project Management, Vol.33 No.6, pp. 1335-1346.

Owusu-Manu, D., Pärn, E., Kutin-Mensah, E. K. and Edwards, D. J. (2018a) Power infrastructure sector reforms, power generation and private investments: empirical evidence from Ghana's power sector. ASCE Journal of Infrastructure Systems, 24(3), pp. DOI: https://doi.org/10.1061/(ASCE)IS.1943$555 \mathrm{X} .0000423$

Owusu-Manu, D., Kukah, A.S., Edwards, D.J., Pärn, E.A., El-Gohary, H. and Hosseini, R. (2018b) An empirical examination of moral hazards and adverse selection on PPP projects: a case study of Ghana. Journal of Engineering, Design and Technology, 16(6), pp. 910-924. DOI: https://doi.org/10.1108/JEDT-01-20180001

Owusu-Manu, D., Edwards, D.J., Ghansah, F.A., Asiedu, O.A. Tagoe, D.S.N. and Birch, T. (2020a) Assessing the Policy Provisions and Institutional Behavioural Factors Influencing Rail Infrastructure Financing in Developing Countries, 
ASCE Journal of Infrastructure Systems, http://doi.org/10.1061/(ASCE)IS.1943$\underline{555 X .0000610 .}$

Owusu-Manu, D., Edwards, D.J., Ghansah, F.A., Asiedu, O.A. Tagoe, D.S.N. and Birch, T. (2020b) Assessing the Policy Provisions and Institutional Behavioural Factors Influencing Rail Infrastructure Financing in Developing Countries, ASCE Journal of Infrastructure Systems, http://doi.org/10.1061/(ASCE)IS.1943$\underline{555 X .0000610 .}$

Owusu-Manu, D., Adjei, T.K., Sackey, D.M., Edwards, D.J. and Hosseini, Reza M. (2020c) Mainstreaming sustainable development goals in Ghana's energy sector within the framework of public-private partnerships: challenges, opportunities and strategies, Journal of Engineering, Design and Technology. DOI: https://doi.org/10.1108/JEDT-06-2020-0255

Owusu-Manu D., Debrah, C., Amissah, L, Edwards, D. J. and Chileshe, N (2020d) Exploring the linkages between project managers mindset behaviour (psychological capital) and project leadership style in the Ghanaian construction industry sector, Engineering Construction and Architectural Management. DOI: https://doi.org/10.1108/ECAM-03-2020-0149

Pärn, E. A., Edwards, D. J. and Sing, M. C. P. (2018) Origins and probabilities of MEP and structural design clashes within a federated BIM model. Automation in Construction, 85, pp. 209-219. DOI:10.1016/j.autcon.2017.09.010

Partnerships Victoria. (2003), Contract management guide. Partnerships Victoria. Australia: Melbourne.

Patterson, C. (1997), Editorial: “Alternative dispute resolution. Resolving dispute with less wear and tear". Journal of Emergency Medicine, Vol.13 No.2 (12), pp. 1214.

Pierre, J. and Peters, G. (2000), Governance, Politics and the State. London: Macmillan.

Ping Ho, S., Levitt, R., Tsui, C-W and Hsu, Y. (2015), “Opportunism focused transaction cost analysis of public-private partnerships". Journal of Management Engineering, Vol. 31, pp.04015007-1-04015007-11 
Pirozzi, M. (2018), “The Stakeholder Management Perspective to increase the Success Rate of Complex Projects". Project Management World Journal, Vol. 7 No.1, pp. 1-12.

Pongsiri, N. (2002), "Regulation and public-private partnerships". International Journal of Public Sector Management, Vol. 15 No. 6, pp.487-495.

Rockart, J.F. (1979), "Chief executives define their own data needs". Harvard Business Review, Vol. 57 No.2, pp. 81-93.

Rousseau, D., Sitkin, S.B., Burt R.S. and Camerer, C. (1998), "Introduction to special topic forum. Not so different after all: a cross-discipline view of trust”. Academy Management Review, Vol. 23 No.3, pp. 393-404.

Sava, E.S. (2000), Privatization and public-private partnerships. New York: Chatham House Publishers.

Schermerhorn, J.R., Hunt, J.G. and Osborn, R.N. (2003), Organizational Behaviour, 8th edition. USA: John Wiely \& Sons.

Schwager, H.P. (2004), Organizational strategies to address stakeholder relationships: A customer portal perspective. $\mathrm{PhD}$ thesis. Aubum University.

Sedgwick, P. (2013), Snowball sampling. Centre for Medical and Healthcare Education, St George's. "University of London, London: United Kingdom.

Taherdoost, H. (2016), Sampling methods in research methodology; How to choose a sampling technique for research", International Journal of Advance Research in Management, Vol. 5 No. 2, pp. 18-27

Taherdoost, H. (2017), "Determining sample size: How to calculate survey sample size”. International Journal of Engineering and Manufacturing Science, Vol. 2, pp. 237-239

Tellefsen, T. and Thomas, G.P. (2005), "The antecedents and consequences of organizational and personal commitment in business service relationships". Industrial Marketing Management, Vol. 34 No. 1, pp. 23-37.

The Department of Sustainability and Environment. (2005), Effective Engagement: Building Relationships with Community and Other Stakeholders. The Community Engagement Network, Resource and Regional Services Division, Melbourne.

The International Organization for Standardization. (2012), Guidance on Project Management. International Organization for Standardization. 
Turkulainen, V., Aaltonen, K. and Lohikoski, P. (2015), "Managing project stakeholder communication: the Qstock festival case". Journal of Project Management, Vol. 46 No. 6, pp. 74-91.

Ullah, F., Ayub, B., Siddiqui, S.Q. and Thaheem, M.J. (2016), “A review of publicprivate partnership: critical factors of concession period". Journal of Financial Management of Property and Construction, Vol.21 No.3, pp. 269-300.

Walker, D.H.T., Bourne, L. and Rowlinson, S. (2008), "Stakeholders and the supply chain". In: D.H.T. Walker and S. Rowlinson (Eds.) Procurement Systems: A cross-industry project management perspective. London: Taylor and Francis.

Wang, Y. (2015), "Evolution of public-private partnership models in American toll road development: learning based on public institutions' risk management". International Journal of Project Management, Vol.33 No.3, pp. 684-696.

Ward, S. and Chapman, C. (2008), "Stakeholders and uncertainty management in projects". Journal of Casting and Materials Engineering, Vol. 26 No.6, pp.563577.

Weaver, D.H. (2007), “Thoughts on agenda setting, framing, and priming”. Journal of Communication, Vol. 57 No.1, pp. 142-147.

Winch, G. (2000), "Construction business systems in the European Union”. Building Research and Information, Vol 28 No.2, pp. 88.

Wood, D.J. and Gray, B. (1991), "Toward a comprehensive theory of collaboration". Journal of Applied Behavioral Science, Vol. 27 No.2, pp. 139-162.

Yang, J., Shen, G.Q., HO, M., Drew, D.S. and Chan, A.P.C. (2009), “Exploring Critical Success Factors for Stakeholder Management in Construction Projects”. Journal of Construction Engineering and Management, Vol.15 No.4, pp. 337-348.

Yang, J., Shen, G.Q., HO, M., Drew, D.S. and Xue, X. (2011), "Stakeholder management in construction: An empirical study to address research gaps in previous studies". International Journal of Project Management, Vol. 29 No.7, pp. $900-910$.

Zhang, X. (2005), “Concessionaire's financial capability in developing build-operatetransfer type infrastructure projects”. Journal of Construction Engineering and Management, Vol. 131 No.10, pp. 1054-1064. 
Table 1 - Critical success factors of stakeholder management

\begin{tabular}{|c|c|c|c|c|c|}
\hline \multirow{2}{*}{ CSFs of Stakeholder Management } & \multicolumn{3}{|c|}{ Shapiro-Wilk } & \multirow[b]{2}{*}{ Stati } & \multirow[b]{2}{*}{ Sig. } \\
\hline & MIS & SD & $\mathbf{R}$ & & \\
\hline Ensuring adequate project planning and control & 4.2 & .8 & 1 & .78 & .00 \\
\hline Providing effective leadership & 4.2 & .8 & 2 & .78 & .00 \\
\hline Formulating appropriate strategies for the management of stakeholders & 4.2 & .9 & 3 & .75 & .00 \\
\hline Confirming clear goals and objectives of the project & 4.2 & .9 & 4 & .75 & .00 \\
\hline Ensuring effective communication & 4.1 & .9 & 5 & .79 & .00 \\
\hline Asserting good governance and consistent monitoring & 4.1 & 1. & 6 & .79 & .00 \\
\hline Preserving and promoting a good relationship by building trust & 4.0 & .9 & 7 & .82 & .00 \\
\hline Promoting commitment among stakeholders & 4.0 & .9 & 8 & .83 & .00 \\
\hline Providing clarity on roles of each stakeholder & 4.0 & 1. & 9 & .82 & .00 \\
\hline Engaging with stakeholders appropriately and frequently & 4.0 & 1. & 10 & .83 & .00 \\
\hline Guaranteeing competitive and transparent procurement approaches & 4.0 & .9 & 11 & .84 & .00 \\
\hline Understanding stakeholders' interest areas (needs and constraints) & 4.0 & 1. & 12 & .82 & .00 \\
\hline Promoting tested legal and regulatory frameworks & 4.0 & 1. & 13 & .82 & .00 \\
\hline Ensuring political support and stability & 3.9 & .9 & 14 & .85 & .00 \\
\hline Formulating a clear statement of project missions & 3.9 & 1. & 15 & .84 & .00 \\
\hline Analyzing and negotiating conflicts and coalitions & 3.9 & 1. & 16 & .85 & .00 \\
\hline Certifying public/community support & 3.8 & 1. & 17 & .84 & .00 \\
\hline Analysing the change of stakeholders' influence and relationships & 3.8 & 1. & 18 & .84 & .00 \\
\hline Predicting stakeholders' reactions for implementing strategies & 3.7 & .9 & 19 & .86 & .00 \\
\hline
\end{tabular}

$M I S=$ Mean item score; $S D=$ Standard deviation; $R=$ Ranking; Significance ( $p$ value) $=$ Sig 